\title{
SOCIAL ISOLATION AND AGGRESSIVENESS IN THE AMAZONIAN JUVENILE FISH Astronotus ocellatus
}

\author{
GONÇALVES-DE-FREITAS, E. ${ }^{1}$ and MARIGUELA, T. C. ${ }^{2}$ \\ ${ }^{1}$ Laboratório de Comportamento Animal, Departamento de Zoologia e Botânica, IBILCE/UNESP, (CAUNESP, RECAW), \\ R. Cristóvão Colombo, 2265, CEP 15054-000, São José do Rio Preto, SP, Brazil \\ ${ }^{2}$ Programa de Pós-Graduação em Zoologia, IB, UNESP, Distrito de Rubião Jr, CEP 18618-000, Botucatu, SP, Brazil \\ Correspondence to: Eliane Gonçalves-de-Freitas, Laboratório de Comportamento Animal, \\ Departamento de Zoologia e Botânica, IBILCE/UNESP, (CAUNESP, RECAW), \\ R. Cristóvão Colombo, 2265, CEP 15054-000, São José do Rio Preto, SP, Brazil, \\ e-mail: elianeg@ibilce.unesp.br \\ Received July 15, 2003 - Accepted March 23, 2004 - Distributed February 28, 2006
}

(With 2 figures)

\begin{abstract}
We tested the effect of social isolation on the aggressiveness of an Amazonian fish: Astronotus ocellatus. Ten juvenile fishes were transferred from a group aquarium $(60 \times 60 \times 40 \mathrm{~cm})$ containing 15 individuals (without distinguishing sex) to an isolation aquarium $(50 \times 40 \times 40 \mathrm{~cm})$. Aggressiveness was tested by means of attacks on and displays toward the mirror image. The behavior was video-recorded for $10 \mathrm{~min}$ at a time on 4 occasions: at $30 \mathrm{~min}, 1$ day, 5 days and 15 days after isolation. The aggressive drive was analyzed in three ways: latency to display agonistic behavior, frequency of attacks and specific attacks toward the mirror image. The latency to attack decreased during isolation, but the frequency of mouth fighting (a high aggressive attack) tended to increase, indicating an augmented aggressive drive. Our findings are congruent with the behavior of the juvenile cichlid, Haplochromis burtoni but differ from the behavior observed in another cichlid, Pterophylum scalare. Increased aggressiveness in A. ocellatus may be mediated by means of the primer effect, the effect of prior residence or processes involving recognition of a conspecific.
\end{abstract}

Keywords: fighting, agonistic display, mirror test, cichlid, apaiari, oscar.

\section{RESUMO}

\section{Isolamento social e agressividade em juvenis do peixe amazônico Astronotus ocellatus}

Testamos o efeito do isolamento social sobre a agressividade no peixe amazônico, Astronotus ocellatus. Dez peixes juvenis foram transferidos de um aquário de agrupamento $(60 \times 60 \times 40 \mathrm{~cm})$ contendo 15 indivíduos (sem discriminação de sexo) para um aquário de isolamento $(50 \times 40 \times 40 \mathrm{~cm})$. A agressividade foi testada por meio de ataques e exibições direcionadas à imagem do peixe no espelho. O comportamento foi filmado durante $10 \mathrm{~min}$ em 4 momentos: $30 \mathrm{~min}, 1$ dia, 5 dias e 15 dias após o isolamento. Nós analisamos a motivação agressiva por meio da latência para início do comportamento agonístico e pela freqüência dos ataques totais e específicos direcionados ao espelho. A latência para o comportamento agonístico reduziu ao longo do isolamento e houve uma tendência de aumento da freqüência de "mouth fighting" (um ataque de alta intensidade de agressão), mostrando-nos um aumento na motivação agressiva. Os resultados estão de acordo com os encontrados para ciclídeos juvenís de Haplochromis burtoni, mas discordam com os encontrados para Pterophylum scalare (acará bandeira). Sugerimos que o aumento da agressividade em A. ocellatus pode ser mediado pelo efeito de exposição prévia, da residência prévia ou por processos envolvendo reconhecimento de co-específicos.

Palavras-chave: lutas, interação agonística, teste do espelho, ciclídeo, oscar. 


\section{INTRODUCTION}

Aggressive interactions are part of the social behavior of animals and are a route to successful competition for limited resources. Several variables can affect aggressive drive in fishes, such as prior residence (Figler \& Einhorn, 1983), dominance or subordination experience (Nelissen \& Andries, 1988), levels of androgens (Munro \& Pitcher, 1983) and social isolation (Gómez-Laplaza \& Morgan, 2000). With regard to the latter factor, there are diverse effects depending on the species, isolation period and other social organization-related factors. For example, Franck \& Wilhelmi (1973) found an increase in the duration of fighting and modification of the agonistic profile in Xiphophorus helleri after 14 days of isolation. However, after longer isolation (4 weeks), Franck et al. (1985) recorded a reduction in the aggressive motivation in the same species. Hinkel \& Maier (1974) found increased aggressiveness in Betta splendens only after $72 \mathrm{~h}$ of social deprivation. They also found a reduction of the latency for attacks and an increase in the time spent on attacks against the fish's mirror image.

Cichlid fishes can also display varied responses. In Haplochromis burtoni, for example, social isolation increases aggressiveness over short periods, but this effect is diminished over longer periods (Fernö, 1978). Moreover, the angelfish, Pterophylum scalare, does not alter its aggressiveness when isolated for short periods (Gómez-Laplaza \& Morgan, 1993). This theme was revised by Gómez-Laplaza \& Morgan (2000) for teleost fishes.

The oscar, Astronotus ocellatus, is a cichlid fish that establishes a dominance hierarchy and defends territory (Beeching, 1997), and is a species of great interest for ornamental purposes. Aquarists consider it a very aggressive fish, so it is commonly found in isolation in pet shops. We aimed to study the effect of short isolation times on the aggressiveness of juvenile Astronotus ocellatus to understand the factors that modulate their aggressive behavior. Our choice also fell on the oscar because it is one of several ornamental species sold in the Amazonian region. In this context, the Aquaculture Center of UNESP (CAUNESP, Brazil) has encouraged a variety of researches on Brazilian ornamental fishes.
We tested the aggressiveness of juveniles Astronotus ocellatus from the Aquaculture Center of UNESP (CAUNESP), Jaboticabal, SP. The fish were kept in a $60 \times 60 \times 40 \mathrm{~cm}$ grouping aquarium (15 fish/140 L) for a 4-month acclimation period during which time we observed no fighting among them. In this phase, the water temperature averaged $25-27^{\circ} \mathrm{C}$, the photoperiod was $12 \mathrm{~L}: 12 \mathrm{D}$ and the fish were fed ad libitum twice a day with special food for cichlid fishes. A biological filter was used to ensure good water quality. Also, the aquarium was siphoned off once a week to remove leftovers and feces from the bottom. Half the water was recycled at this time. The study was conducted at the Animal Behavior Laboratory of IBILCE, UNESP.

The general design consisted of isolating fish during 15 days and testing aggressiveness on 4 different occasions during this period. To this end, we used juveniles (without distinguishing sexes) $5.99 \pm 0.62 \mathrm{~cm}$ SL long, weighing $8.98 \pm 2.64 \mathrm{~g}(n=10)$. The fish were caught in the grouping aquarium, anesthetized with benzocaine $(2: 5,000)$ and isolated in a $50 \times 40 \times 40 \mathrm{~cm}$ aquarium with a gravel bottom and a biological filter. The water temperature averaged $27 \pm 1.5^{\circ} \mathrm{C}$ and the photoperiod was $12 \mathrm{~L}: 12 \mathrm{D}$. The right and back walls of each aquarium were covered with blue cards to prevent visual contact between neighboring fish. Blue was chosen due to its stressreducing effect on fish (Volpato \& Barreto, 2001). The left wall was left free for mirror presentation and the front was for behavioral recording. The fish were fed ad libitum mornings and afternoons with special food for cichlid fish.

Aggressiveness was evaluated based on the fishes' attacks and aggressive displays to a mirror, as described by Hinkel \& Maier (1974) and Franck et al. (1985). The mirror image test is an experimental paradigm used to study social deprivation in fishes, and although this paradigm has been criticized (see Gómez-Laplaza \& Morgan, 1993), it is a valid method to measure aggressive motivation in cichlids and salmonids (Holder et al, 1991). The mirror test barely resembles the natural condition of agonistic interaction. However, the condition is more standardized, since the image is of the same size and behaves in the same way as the aggressor (Franck et al., 1985), thus avoiding varied effects of the opponent on the aggressor's response. 
The mirror was presented to the animal on 4 occasions: $30 \mathrm{~min}$ (Day-0), $24 \mathrm{~h}$ (Day-1), 5 days (Day-5) and 15 days (Day-15) after isolation, and video-recorded the fish's behavior for 10 min each time. The timing of these periods was chosen in order to compare the evolution of behavioral response over time. The two first occasions were considered the control condition, in which individuals may show no effect of social deprivation. The third occasion was considered a short-term isolation, and the fourth a long-term isolation, similar to those applied by Fernö (1978) on the juvenile cichlid Haplochromis burtoni (in that case, the fish was studied from $15 \mathrm{~min}$ to 12 days of social deprivation).

We drew up an ethogram of agonistic behavior based on Baerends \& Baerends-Van Roon's (1950) descriptions of agonistic interactions in cichlids. Aggressiveness was defined based on the frequency of attacks on and aggressive displays toward the mirror, and also by the latency to start such behavior.

We observed 4 types of aggressive events displayed to the mirror:

- Mouth Fighting: The fish touches and pushes the mirror with its mouth, swimming up and down while undulating its body;

- Butting: the fish approaches the mirror and touches it quickly with its mouth;

- Tail Beating: The fish hovers parallel to the mirror and undulates its body, beating its tail against the glass. This behavior can occur with the mouth in a horizontal position or pointing towards the substrate;

- Frontal Display: The fish faces its image in the mirror, undulating its body and swimming up and down a few centimeters away from the mirror; and

- We considered the Total Fighting as the sum of all agonistic events.

Fishes were killed with an overdose of benzocaine at the end of the isolation period and dissected to check the developmental stage of their gonads.

The outlier values were removed before the statistical tests were conducted (Volpato, 2001). The normality of the data was then tested by Shapiro Wilk's test (Zar, 1999). Since normality was not detected, we analyzed the frequency of agonistic behaviors and the latency by Friedmann's ANOVA completed with Tukey's post hoc test (Zar, 1999), considering $\mathrm{p} \leq 0.05$ for statistical significance.

Because no contests were observed on Day-0, we analyzed only the remaining three days. Friedman's ANOVA indicated no significant differences for Total Fighting, Butting, Tail Beating and Frontal Display frequencies $(\mathrm{P}=0.08$; Fig. 1). However, a tendency was found for increasing frequency of mouth fighting. In this case, Tukey's comparison indicated $\mathrm{p}=0.06$ from Day- 1 to Day-15 (Fig. 1).

The latency for starting attacks decreased over the 15 days (Friedman ANOVA, $\mathrm{p}=0.028$; Fig. 2). According to Tukey's test comparison, the difference was significant from Day-1 to Day-15 $(p=0.014)$ but did not differ on the other days $(\mathrm{p}>0.20)$.

Macroscopic analyses of gonads revealed the immaturity of all the tested fish. The gonads were so thin that it was impossible to ascertain the sex of the animals, which confirmed the fish were juveniles.

No attacks occurred on Day-0 and the animals lay on their sides at the bottom of the aquaria. Although this behavior resembles "resting", as described by Baerends \& Baerends-Van Roon (1950), it could be considered a stress indicator in this species because immobility can be associated with a typical fright reaction reported for other fishes (e.g., Barlow et al., 1986; Gómez-Laplaza \& Morgan, 1986). According to Gómez-Laplaza \& Morgan $(1993 ;$ 2000), patterns of aggressive behavior may be influenced by transfer effect, as described for Pterophylum scalare, which showed reduced aggressiveness after being transferred from one aquarium to another (Gómez-Laplaza \& Morgan, 1993). Thus, we concluded that the absence of aggression and the reduced activity on Day-0 of our study were caused by handling-related stress during the transfer from grouping to isolating aquaria.

The frequency of total fighting displayed to the mirror image did not change during isolation (Fig. 1) and did not indicate increased aggressiveness. However, a detailed analysis of specific types of aggressive behavior revealed no significant changes in the behavior, but an increasing tendency for mouth fighting, which seems to be the most aggressive behavior exhibited by the oscar (Fig. 1). 


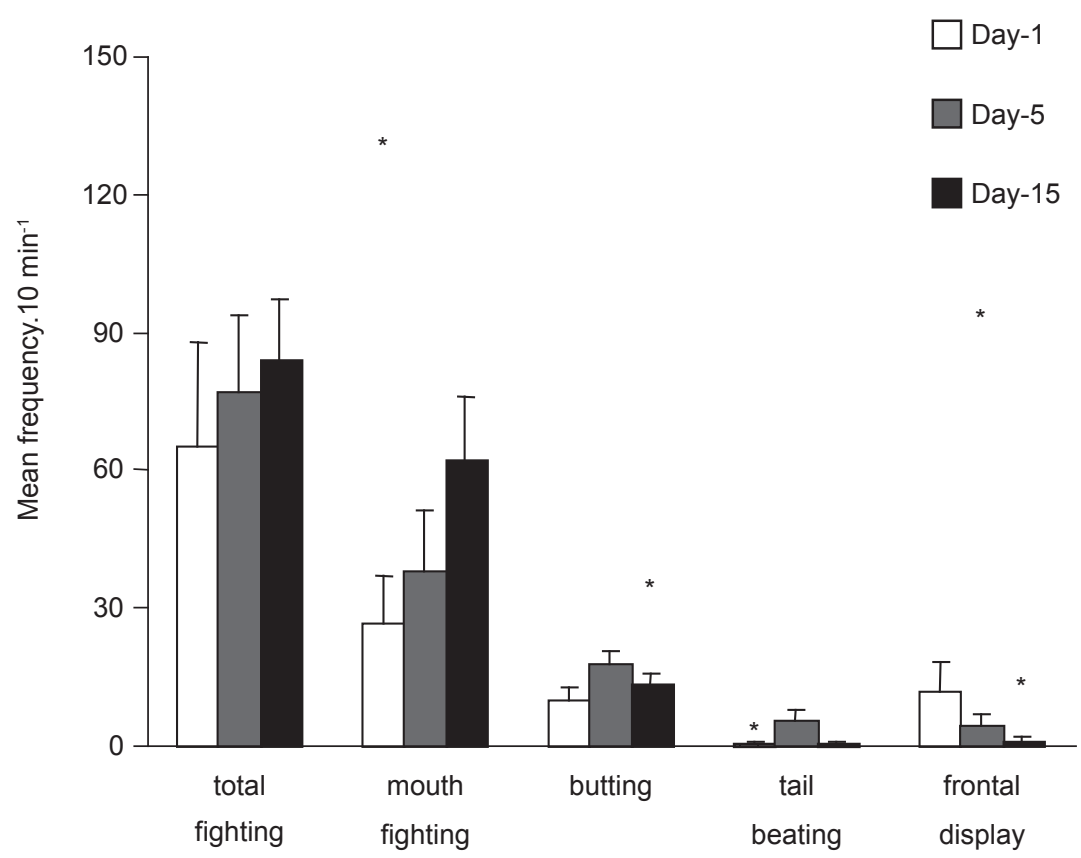

Agonistic behavior

Fig. 1 - Mean Frequency $( \pm \mathrm{sd})$ of agonistic behaviors toward the mirror image. There was no significant difference during the period of isolation (Friedman ANOVA). However, an increasing tendency was detected for mouth fighting. Outliers are indicated with an asterisk.

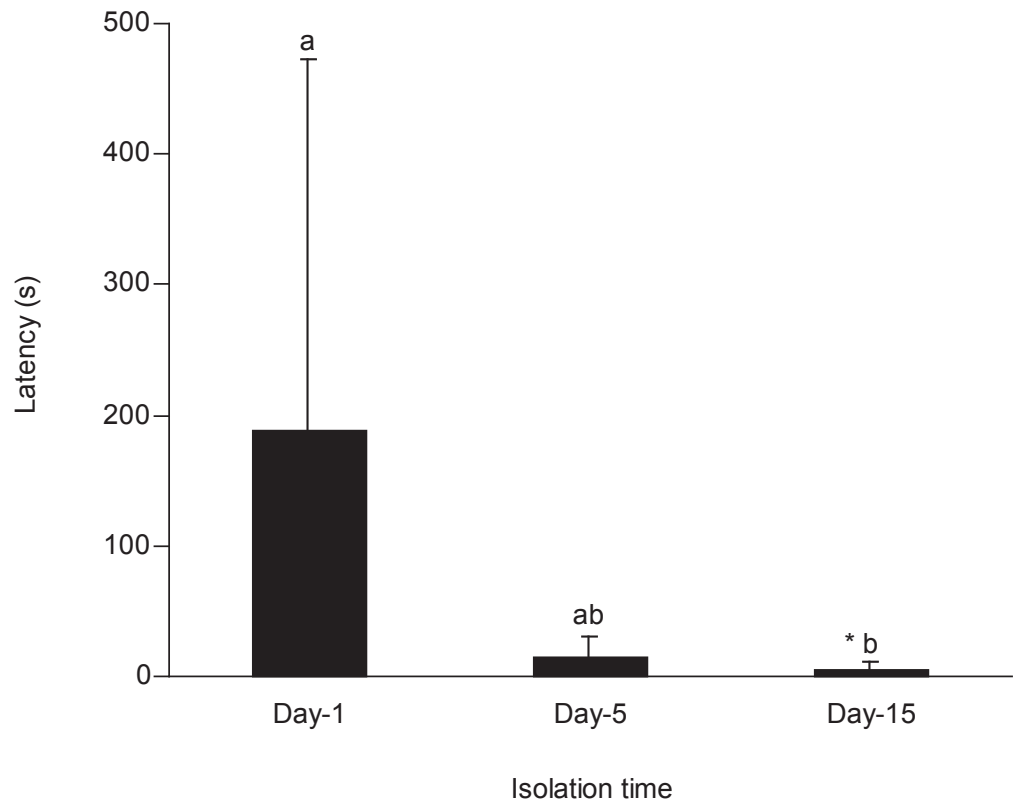

Fig. 2 - Mean latency $( \pm \mathrm{sd})$ to start agonistic behavior toward the mirror image. Bars with the same letters have no statistical difference (Friedman ANOVA completed with Tukey post hoc test). Outlier is indicated with an asterisk. 
Gómez-Laplaza \& Morgan (1993) considered High Intensity Attack (HIA) and Low Intensity Attack (LIA) for Pterophylum scalare juveniles. Although their definition was based on the behavior of the aggressor and the recipient (while we have only the aggressor), we considered mouth fighting a High Intensity Attack because it lasts longer than do the other behavioral units and is carried out while swimming rapidly toward the mirror image. Thus, we considered this increasing tendency in mouth fighting frequency an indicator of increasing aggressiveness in $A$. ocellatus.

Although we found no significant differences in behavioral frequency, the latency to attack the mirror image decreased significantly over time during the period of isolation (Fig. 2). Reduced latency indicates increased aggressiveness, as observed for Cichlasoma nigrofasciatum (Figler et al., 1986). Moreover, Fernö (1978) found an increased latency to fight in Haplochromis burtoni after 3 days of isolation, which was associated with a reduced aggressive drive, confirming that aggressive motivation can be adequately inferred from this parameter.

We found that social isolation increases aggressive drive in oscars, but this finding is not congruent with other studies. Gómez-Laplaza \& Morgan (1986; 1993) found no increased aggressiveness after either 4 or 10 days of isolation in juvenile cichlid Pterophylum scalare. These authors concluded that juvenile cichlid fish kept in isolation are less likely to behave aggressively, at least during a few days of social deprivation. However, that is not the case with oscars, which seem more aggressive than Pterophylum scalare since latency for fighting decline over the 15 days in social isolation.

According to Goldenbogen (1977) apud Gómez-Laplaza \& Morgan (2000), H. burtoni juveniles also increase aggressiveness in response to social isolation. However, the aggressiveness of adults of such species declines after three days of isolation (Fernö, 1978) indicating the effect of the development stage in this condition.

No agonistic interaction was observed among the tested fish when they were reared together in the grouping aquarium. Thus, social deprivation really stimulated aggression in Oscars, which continued to increase up to day 15 of isolation, when it reached its peak (Figs. 1 and 2).
There may be several explanations for this result. Firstly, the mirror image may have worked as a primer in the oscar, as observed in Betta splendens (Halperin et al., 1992). In that study, the authors showed a fish-model at 2-min intervals every 2 days for 3 weeks. Although the oscar was not overexposed to its mirror image and remained in complete isolation during the ten final days (between Day-5 and Day-15), we do not discard the possibility of a priming effect causing augmented aggressiveness. Secondly, it is possible that fishes that grow up together recognize each other and do not fight, at least not before they reach sexual maturity. Some studies demonstrated that individual recognition plays an important role in reducing aggression in contests of adult and juvenile fishes (e.g., Giaquinto \& Volpato, 1997; Johnsson, 1997). Moreover, visual and chemical information is necessary to complete recognition of social status in juvenile Nile tilapia (Giaquinto \& Volpato, 1997). Thus, the mirror image may also give the oscar some incomplete information about the "opponent", since there is no chemical communication between the "combatants", stimulating continuous attacks from the aggressor. Thirdly, probably a prior residence effect occurred (e.g., Figler \& Einhorn, 1983; Figler et al., 1986; Turner, 1994), which can be established through isolation in many cichlids. An increased level of aggression in the absence of competitors may be advantageous because it increases the chance to win contests against conspecific intruders (GómezLaplaza \& Morgan, 2000). Moreover, similar size between the "combatants" produces a symmetrical contest that increases aggression in A. ocellatus (Beeching, 1992). This fact and prior residence can keep aggressiveness high (Turner, 1994).

Sex hormones, which can affect aggressiveness in fish (Munro \& Pitcher, 1983), probably had no effect on the behavior of these oscars since they were juveniles, as confirmed by macroscopic analysis of the gonads. In short, this study showed that long-term social isolation increases aggressiveness in juvenile $A$. ocellatus, and that not all cichlids display a similar effect. Priming effect, residence effect and recognition of the opponent are cues that can govern this behavior.

Acknowledgments - The authors are indebted to João B. K. Fernandes (CAUNESP, Jaboticabal) for donating the fish; to Roselene S. C. Ferreira and Carlos Eduardo de Souza 
(IBILCE, UNESP) for their technical support; to Dr. Carlos C. Alberts (UNESP, Assis) for translating the paper by Franck D. \& Wilhelmi U. (1973); to Dr. Gilson L. Volpato (UNESP, Botucatu) for suggestions on data analysis; and to André L. S. Castro and Aline C. Ferreira for their invaluable assistance and profitable discussions during development of this study.

\section{REFERENCES}

BAERENDS, G. P. \& BAERENDS-VAN ROON, J. M., 1950, An introduction to the study of the ethology of cichlid fishes. Behaviour Suppl., 1: 1-242.

BARLOW, G. W., ROGERS, W. \& FRALEY, N., 1986, Do midas cichlids win through prowess or daring? It depends. Behav. Ecol. Sociobiol., 19: 1-8.

BEECHING, S. C., 1992, Visual assessment of relative body size in a cichlid fish, the Oscar, Astronotus ocellatus. Ethology, 90: 177-186.

BEECHING, S. C., 1997, Functional groups in the social behavior of a cichlid fish, the oscar, Astronotus ocellatus. Behav. Process., 39: 85-93.

FERNÖ, A., 1978, The effect of social isolation on the aggressive and sexual behaviour in a cichlid fish, Haplochromis burtoni. Behaviour, 65: 43-61.

FIGLER, M. H. \& EINHORN, D. M., 1983, The territorial prior residence effect in convict cichlids (Cichlasoma nigrofasciatum GÜNTHER): Temporal aspects of establishment and retention, and proximate mecanisms. Behaviour, 85: 157-183.

FIGLER, M. H., CANOUNE, H. L. \& KITNER-TRIOLO, M. H., 1986, The effects of duration of territorial residence on aggression in convict cichlids. Bull. Psych. Soc., 24: 465-466.

FRANCK, D. \& WILHELMI, U., 1973, Veränderungen der aggressiven Handlungsbereitschaft männlicher Schwertträger, Xiphophorus helleri, nach sozialer Isolation (Fische, Poeciliidae). Experientia, 29: 896-897.

FRANCK, D., HANNES, R. P., LANFFERMANN, H. \& RIBOWSKI, A., 1985, Effects of social isolation on aggressiveness in fish with special reference to the swordtail (Xiphophorus helleri). Behav. Process., 10: 415-427.

GIAQUINTO, P. C. \& VOLPATO, G. L., 1997, Chemical communication, aggression, and conspecific recognition in the fish Nile tilapia. Physiol. Behav., 62: 1333-1338.
GÓMEZ-LAPLAZA, L. M. \& MORGAN, E., 1986, Towards an isolation syndrome for the angelfish, Pterophyllum scalare. J. Fish Biol., 29 (Supplement A): 179-187.

GÓMEZ-LAPLAZA, L. M. \& MORGAN, E., 1993, Social isolation, aggression, and dominance in attacks in juvenile angelfish, Pterophyllum scalare. Aggress. Behav., 19: 213-222.

GÓMEZ-LAPLAZA, L. M. \& MORGAN, E., 2000, Laboratory studies of the effects of short-term isolation on aggressive behaviour in fish. Mar. Fresh. Behav. Physiol, 33: 63-102.

HALPERIN, J. R. P., DUNHAM, D. W. \& YE, S., 1992, Social isolation increases social display after priming in Betta splendens but decrease aggressive readiness. Behav. Process., 28: 13-32.

HINKEL, T. J. \& MAIER, R., 1974, Isolation and agression in siamese fighting fish (Betta splendens). Psychol. Reports, 34: 1323-1326.

HOLDER, J. L., BARLOW, G. W. \& FRANCIS, R. C., 1991, Differences in aggressiveness in the midas cichlid fish (Cichlasoma citrinellum) in relation to sex, reprodutive state and the individual. Ethology, 88: 297-306.

JOHNSSON, J., 1997, Individual recognition affects aggression and dominance relations in Rainbow Trout. Oncorhynchus Mykiss. Ethology, 103: 267-282.

MUNRO, A. D. \& PITCHER, T. J., 1983, Hormones and agonistic behavior in teleosts, pp. 155-175. In: J. C. Rankin, T. J. Pitcher \& R. T. Duggan (eds). Control Processes of Fish Physiology. London: Croom Helm.

NELISSEN, M. H. J. \& ANDRIES, S., 1988, Does prior experience affect the ranking of cichlid fish in a dominance hierarchy? Annls. Soc. R. Zool. Belg., 118: 41-50.

TURNER, G. F., 1994, The fighting tatics of male mouthbrooding cichlids: the effects of size and residency. Anim. Behav., 47: 655-662.

VOLPATO, G. L., 2001, Ciência: da filosofia à publicação. FUNEP, Jaboticabal, SP. 216p.

VOLPATO, G. L. \& BARRETO, R. E., 2001, Environmental blue light prevents stress in the fish Nile tilapia. Braz. $J$. Med. Biol. Res., 34: 1041-1045.

ZAR, J., 1999, Biostatistical Analysis. $4^{\text {th }}$ edn. New Jersey: Prentice Hall. $663+266 \mathrm{p}$. 